\title{
METODA PENDUGA BOBOT SAPI DENGAN TEKNOLOGI \\ PENGOLAHAN CITRA (Image Prosesing)
}

\author{
Oleh : \\ UJANG SURYADI*), AMAL BAHARIAWAN **)
}

\begin{abstract}
Penentu bobot badan sapi berdasarkan ukuran tubuh bertolak dari anggapan bahwa tubuh sapi itu berupa sebuah tong. Pengukuran bentuk tubuh sapi dari tiga kondisi yaitu depan, belakang, dan samping dapat dilakukan dengan mengaplikasi teknolgi citra digital. Proses pengolahan citra digital dilakukan dengan cara'mengambil obyek citra menggunakan kamera digital dan kemudian dilakukan pengolahan citra sesuai yang diinginkan dengan menggunakan progam Pascal. Dari pengolahan citra ini akan dihasilkan ukuran luas, keliling dari bagian sapi yang di citra. Nilai yang diperoleh ini akan dapat menggambarkan bobot badan sapi dan juga penafsiran tentang berat karkas. Tujuan yang ingin dicapai dalam penelitian ini adalah : menentukan bobot badan sapi dan juga penafsiran berat karkas dengan menggunakan teknik citra digital. Dari kegiatan penelitian ini dapat diambil kesimpulan sebagai berikut : (a) Algoritma pendugaan berat sapi telah disusun berdasarkan model linier antara berat sapi dengan luas proyeksinya dengan persamaan model linier $\mathrm{y}=14.083 \mathrm{x}$ +178.58 dan nilai koefisien determinasi $\quad\left(\mathrm{R}^{2}=0.8815\right)$, (b) Model pendugaan berdasarkan model linier antara berat sapi dengan luas piksel proyeksinya dapat dikembangkan lebih lanjut karena koefisien detetrinasinya sangat tinggi, (c) Dibandingkan dengan hasil pengukuran berat sapi secara langsung maka pendugaan berat sapi berdasarkan luas proyeksi citra mempunyai ketepatan $80 \%$.
\end{abstract}

Kata Kunci: bobot sapi, citra digital, karkas

\section{PENDAHULUAN}

Pendugaan dan pengukuran tubuh sapi sering diperlukan, bahkan keterampilan dalam menduga dan mengukur merupakan suatu hal yang mutlak harus dikuasai seorang peternak atau yang berkecimpung dalam dunia peternakan karena dalam kondisi di lapangan, keadaan peralatan serta fasilitas lainnya yang diperlukan untuk menentukan parameter yang ingin diperoleh sering kali sulit ditentukan.

Pendugaan bobot badan sapi supaya tidak meleset jauh dari sebenarnya diperlukan alat pengukur lainnya walaupun hasilnya tidak setepat timbangan sapi. Alat pengukur yang biasa digunakan untuk memperkirakan bobot badan sapi maupun untuk ternak Iainnya adalah pita ukur. Hasil pengukuran terhadap bagian tubuh sapi dengan menggunakan pita ukur dapat dipergunakan sebagai parameter teknis penentuan bobot sapi. Ukuran tubuh yang digunakan untuk menduga bobot tubuh biasanya adalah panjang badan dan lingkar dada.

Berbagai rumus penentu bobot badan sapi berdasarkan ukuran tubuh telah banyak diketahui, bahkan berbagai penelitian telah menggunakan rumus tersebut disesuaikan dengan keadaan lingkungan, pengaruh genetis, dan waktu. Rumus penentu bobot badan berdasarkan ukuran tubuh bertolak dari anggapan bahwa tubuh sapi itu berupa sebuah tong. Pengukuran bentuk tubuh sapi dari tiga kondisi yaitu depan, belakang, dan samping dapat dilakukan dengan mengaplikasi teknolgi citra digital. Proses pengolahan citra digital dilakukan dengan cara'mengambil obyek citra menggunakan kamera digital dan kemudian dilakukan pengolahan citra sesuai yang diinginkan dengan menggunakan progam Pascal. Dari pengolahan citra ini akan dihasilkan ukuran luas, keliling dari bagian sapi yang di citra. Nilai yang diperoleh ini akan dapat menggambarkan bobot badan sapi dan juga penafsiran tentang berat karkas. 


\section{METODOLOGI}

\section{Tempat dan Jangka Waktu Penelitian}

Pelaksanaan penelitian dilakukan di tiga tempat yaitu : pembuatan peralatan pengolahan citra dilakukan di Laboratorium Instrumentasi, pembuatan soft ware Pemrograman dengan Visual Basic dilakukan di Lab Komputer, sedangkan pengujian di lakukan di Laboratorium Produksi Ternak. Waktu penelitian dilakukan selama 6 bulan.

\section{Alat dan Bahan Penelitian}

Bahan Penelitian

Bahan penelitian yang digunakan dalam penelitian ini adalah sapi dari berbagai ukuran sebanyak 10 sapi yang sudah diketahui karakteristik sapi seperti berat, lingkar dada.

Alat Penelitian

Peralatan yang dipergunan adalah kamera Digital Canon 8 Mega pixel, seperangkat komputer dengan prosesor Pentium $11350 \mathrm{MHz}$, RAM 128 MB, Perangkat lunak yang digunakan sebagai perangkat bingkai citra adalah ASUS-Live 3000. Untuk pengolahan citra digunakan algoritma yang disusun menggunakan bahasa Visual Basic versi 6.0 .

\section{Prosedur Penelitian}

a. Pengambilan Citra dengan Sistem Pengolahan Citra

Bahan sapi yang disampingnya diletakkan benda berbentuk lingkaran yang sudah diketahui luasnya diambil citranya dengan kamera Digital dengan sistem pengolahan citra dilakukan pada kondisi sebagai berikut: sapi tampak samping, sapi tampak belakang

- Citra yang telah terekam akan dikonversi dari citra analog menjadi citra digital selanjutnya disimpan dalam bentuk file citra berukuran $288 \times 352$ pxel dalam format RGB

- Citra yang telah terekam, disimpan dalam sebuah file dengan ekstensi bmp untuk analisis citra lebih lanjut.

b. Analisis luas proyeksi dan Berat Sapi

Sapi yang didapat kemudian dianalisis luasnya berdasarkan luas proyeksinya. Selanjutnya dibuat model linier hubungan antara luas sapi hasil analisa dengan berat sapi. Selain itu juga dibuat model linier hubungan antara berat sapi dengan luas proyeksi sapi. Model linier yang memiliki koefisien determinasi tinggi (R2) > 0.9 dapat digunakan sebagai model pendugaan berat sapi.

c. Validasi

Validasi digunakan untuk mengetahui keterandalan model yang telah dibuat. Validasi dilakukan dengan cara menganalisis sapi secara manual hingga diketahui beratnya. Kemudian dilakukan pendugaan berat dengan teknik pengolahan citra dilakukan dengan menyusun program pengelompokan (clustering) berdasarkan kriteria standar berat yang telah ditetapkan. Selanjutnya dibandingkan hasil berat yang dilakukan secara manual dengan pengukuran berat yang dilakukan dengan teknik pengolahan citra. Semakin kecil persentase kesalahan pendugaan mutu oleh teknik pengolahan citra maka semakin akurat model pengukuran yang dikembangkan. 


\section{HASIL DAN PEMBAHASAN}

\section{Pengolahan Citra Sapi}

Perekaman citra sapi dilakukan menggunakan kamera CCD dengan LiveCam Visa IM dengan resolusi 288 x 352 piksel seperti Gambar 1. di bawah ini. Hasit perekaman digitasi disimpan dalam memori hardisk untuk analisis citra Iebih lanjut.

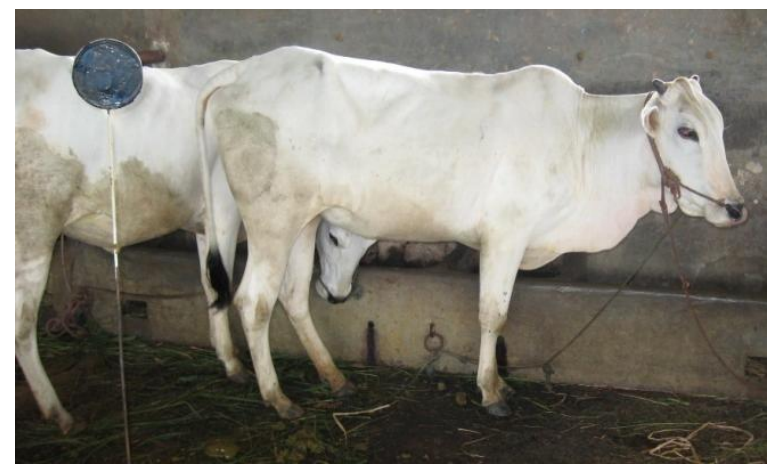

Gambar 1. Tampilan perekaman citra sapi

Program pengolahan citra sapi ini terdiri dari tombol-tombol yaitu: 1) tombol untuk mengambil (load) citra yang tersimpan dalam memori hardisk; 2) tombol untuk menyalin citra pada frame citra ke-2; 3 ) tombol perintah thresholding; 4) tombol binerisasi; 5) tombol perhitungan perimeter, panjang, leba,dan luas proyeksi; 6) tombol penentuan kelas mutu; dan 7) tombol keluar program.

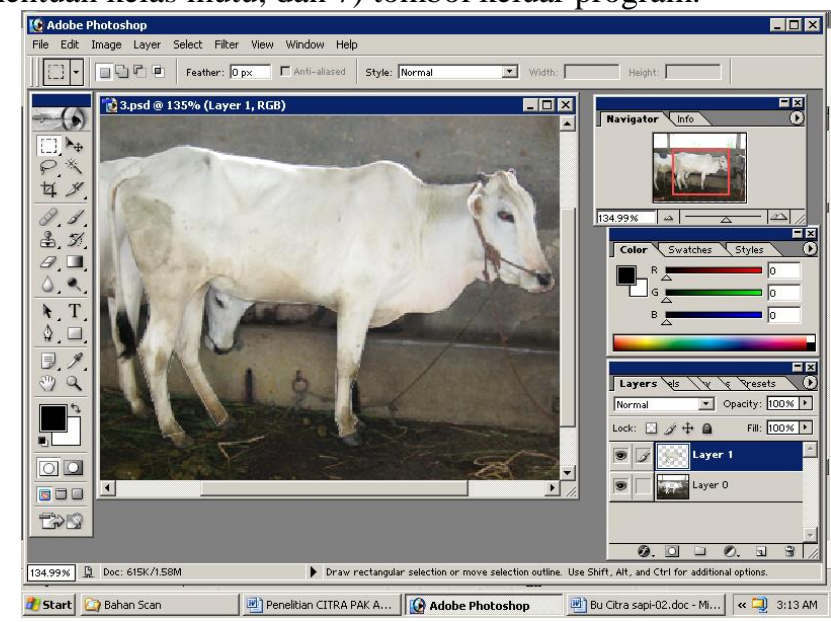

Gambar 2. Tampilan awal program pengolahan citra

Citra dipanggil dengan menekan tombol load image, maka akan muncul kotak dialog open file. File citra yang dipilih akan ditampilkan pada kotak citra (picture box). Citra tersebut selanjutnya disalin pada pada kotak citra ke-2 untuk proses thresholding dengan menekan tombol copy Objek. 


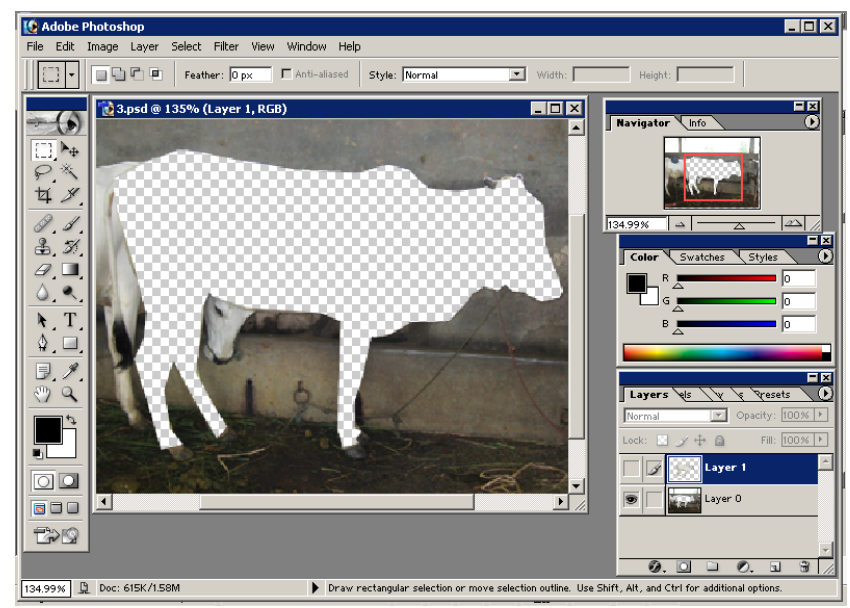

\section{Gambar 3. Tampilan program saat tresholding}

Selanjutnya citra dibinerisasi yaitu hanya memberikan dua nilai ntensitas pada citra. Piksel obyek akan diwakili oleh warna hitam $((\operatorname{RGB}=(0,0,0))$, dan piksel latar diwakili oleh warna putih $(\operatorname{RGB}=(255,255,255))$, seperti ditunjukkan pada Gambar 3.

Tujuan binerisasi citra adalah untuk mempermudah mendapatkan data-data pengolahan citra yang diharapkan. Setelah binerisasi dilanjutkan dengan perhitungan nilai-nilai perimeter, luas proyeksi citra sapi dan benda lingkaran standar.

Kemudian dengan memasukkan luas proyeksi maka program akan memproses masukan tersebut yang hasilnya akan ditampilkan pada kota teks luas citra.

\section{Pendugaan luas, dan Berat Sapi}

Pendugaan luas proyeksi sapi dan berat sapi dilakukan dengan menggunakan analisis regresi linier. Melalui regresi linier ini dibangun model pendugaan nilai $\mathrm{Y}$ (nilai sebenarnya) atas nilai panjang, dan berat sapi melalui teknik pengolahan citra. Menurut Mattjik dan Sumertajaya (2000) keterandalan model yang diperoleh dapat dilihat dari kemampuan model menerangkan keragaman nilai peubah Y. Ukuran ini sering disebut sebagai koefisien determinasi yang dilambangkan dengan huruf $\mathrm{R}^{2}$. Semakin besar nilai $\mathrm{R}^{2}$ berarti model semakin mampu menerangkan perilaku peubah $\mathrm{Y}$, dimana kisaran nilai R2 mulai dari 0\% sampai $100 \%$.

Nilai dugaan berat sapi didapatkan melalui proses thresholding dan binerisasi. Dilanjutkan dengan menekan tombol perintah binerisasi yang akan menghitung luas citra tampilan sapi dari samping, belakang dan depan yang kemudian dibandingkan dengan luas citra benda lingkaran standar yang sudah diketahui luas sebenarnya yang dapat diduga oleh luas piksel.

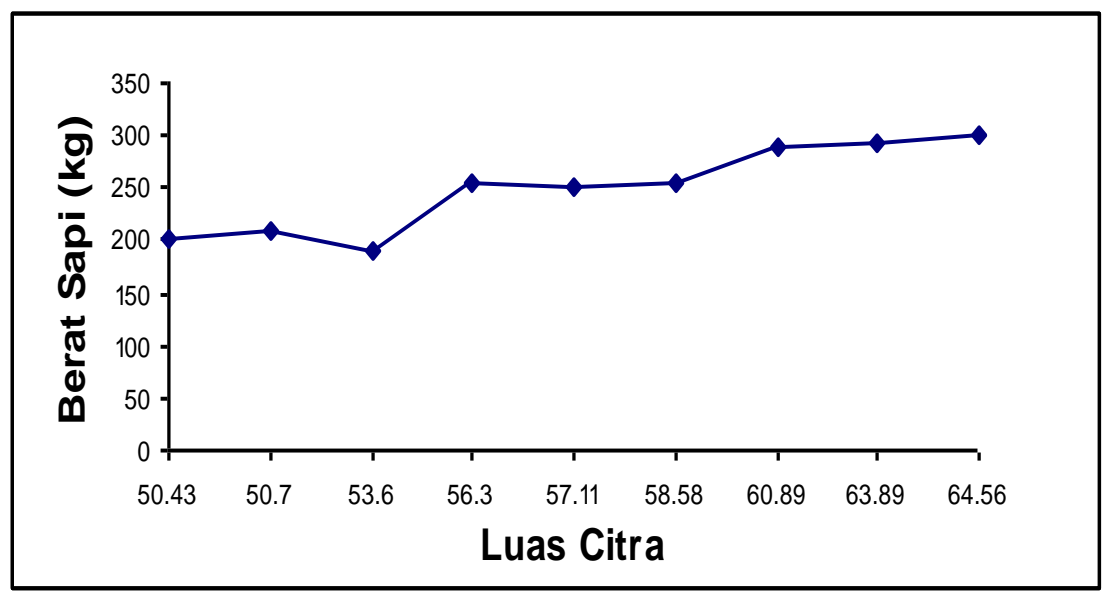

Gambar 4. Hubungan luas proyeksi sapi dengan berat sebenarnya. 
Berdasarkan grafik hubungan antara luas proyeksi sapi dengan berat aktualnya pada Gambar 4 diperoleh nilai $\mathrm{R}^{2}=0.8815$ dengan persamaan model linier $y=14.083 x+178.58$ Nilai $R 2$ tersebut sangat tinggi, sehingga pendugaan berat sapi berdasarkan luas proyeksinya sangat memungkinkan.

\section{KESIMPULAN DAN SARAN}

\section{Kesimpulan}

Kesimpulan yang bisa diambil dari penelitian pengembangan algoritma pendugaan berat sapi menggunakan pengolahan citra ini adalah:

a. Algoritma pendugaan berat sapi telah disusun berdasarkan model linier antara berat sapi dengan luas proyeksinya dengan persamaan model linier $\mathrm{y}=$ $14.083 x+178.58$ dan nilai koefisien determinasi $\quad\left(\mathrm{R}^{2}=0.8815\right)$

b. Model pendugaan berdasarkan model linier antara berat sapi dengan luas piksel proyeksinya dapat dikembangkan lebih lanjut karena koefisien detetrinasinya sangat tinggi.

c. Dibandingkan dengan hasil pengukuran berat sapi secara langsung maka pendugaan berat sapi berdasarkan luas proyeksi citra mempunyai ketepatan $80 \%$.

\section{Saran}

Perlu dikembangkan model pendugaan yang lain seperti pendugaan terhadap nilai karkas sapi, sehingga untuk perhitungan nilai jual daging dapat diprediksi.

\section{DAFTAR PUSTAKA}

Ahmad Usman, (2002). Teknik Dasar Pengolahan Citra Digital, Jurusan Teknik Pertanian Fakultas Teknologi Pertanian Institut Pertanian Bogor, Bogor.

Berg, R.T., dan R.M. Butterfield. 1976. New Concepts of Cattle Growth. Sidney University Press.

Crouse, J.D., H.R. Cross dan S.C. Seideman. 1985. Effect of sex Condition,
Genotype, Diet and Carcass Electrical Stimulation on Collagen Content and Palatability of Two Bovin Muscles. J.Anim. Sci. 60 : 1228 1234.

Crouse, J.D., L.V. Cundiff, R.M. Kock, M, Kooh Maraie dan S.C Seideman. 1978. Comparisions of Bos-Indicus dan Bos Taurus Inheritance for Carcass Beef Characteristics and Meat Palatability. J. Anim. Sci. 67: 2661-2668.

Gerrard, D.E., S.J. Jones, E.D. Aberle, R.P. Lemenager, M.A. Diekman dan M.D. Judge. 1987. Collagen Stability, Testosterom Secretion and Meat Tenderness in Growing Bulls and Steers. J.Amin.Sci. 65: 12361242.

Judge, M.D., ED. Aberle, H.R. Cross dan B.D. Schanbacher. 1989. Thermal Shrikage Temperature of Intramuscular Collagen of Bulls and Steers. J.Amin.Sci. 59: $706-709$.

Kempster, T., C., Alastair dan H. Geof., 1982. Carcase Evaluation in Livestock Breeding, Production and Marketing. $1^{51} \mathrm{Ed}$. Granada Publishing Ltd. USA

Lawrie, R.A. 1985. Meat Science. $4^{\text {h }}$ Ed. Pergamon Press, Oxford-New YorkSidney-ParisFrankfurt.

1988 Meat Science. $4^{\text {h }}$ Ed. Pergamon Press. Oxford-New YorkSidney-ParisFrankfurt. 
Jurnal IImiah INOVASI, Vol.13 No.1, Hal. 79-83, Januari-April 2013, ISSN 1411-5549

Paschal, J.C., J.O. Sanders, J.L. Kerr, Lunt, dan A.D. Herring. 1995 .

Postweaning and

Feedlot Growth and

Carcass Characteristics of Angus, Gray Brahman, Gir-, Indu Brazil, Nellore, and Red Brahman - Sired F, Calves. J. Anim. Sci. 73: 373-380 